\title{
The Ten First Implementations to prove that "The Harmony in Gradation" is "The Formula Everything"
}

\section{Sigit Haryadi, 17 March 2018}

\section{Paper DOI 10.17605/OSF.IO/59SZB}

\begin{abstract}
"The Harmony in Gradation" is a formula that combines two contradictory elements, namely "The Harmony" and "The Gradation" which no one has ever thought that the two can be combined in one formula, which is why this new formula is believed by the author as a "The Formula of Everything", a formula that can be used in all branches of science. This paper lists ten implementations of "The Harmony in Gradation" or "The Fairness over Inequality" in various branches of science, to replace or only as a complement of the formulas that are still used, among others: Herfindahl Index conveyed in 1950, Gini Index (1909), Information "Shannon" Entropy (1948), Consistency "Pauli \& Kraepelin" Test (1938), and Pearson Correlation (1893).

This paper was written to invite experts in their respective fields, to test whether the inventor's belief of this formula is worthy of consideration, and with the means and background to prove it, for which an internet calculator is provided for this in the address http://sigitharyadi.net
\end{abstract}

\section{The Harmony in Gradation}

The Harmony in Gradation is the formula I created on April 28, 2016, which was originally named as "Haryadi Index", and only focus to use in the Competition Law field, to replace the Herfindahl Index I've been using. After studying for two years, I believe that this formula can be used as an alternative to replace or complement existing methods, because in the formula both contain two contradictory things, no one has ever thought to merge them, namely "The Harmony" and "The Gradation, on the other hand, the existing formulas contain only one element.

The formula "Harmony in Gradation" is written as follows:

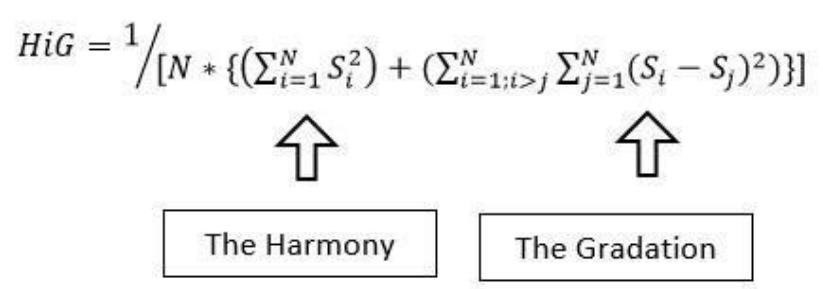

Where: HiG is "the Harmony in Gradation" of a random variable (or set) which has a sample population (or subset) $=\mathrm{N}$, and $\mathrm{Si}$ is "the Share" of each sample (or subset) = comparison 
between strengths or the value of each sample (or subset) with the total strength of the random (or set) variable.

Examples of the Haryadi Index or the Harmony in Gradation formulas are as follows: (a) for a random variable (or set) that has two samples (or subsets): HI (2), (b) for a random variable (or set) which has three samples (or subset): HI (3), (c) for a random variable (or set) that has four samples (or subset): HI (4)

$\mathrm{HI}(2)=1 /\left[2\left\{\mathrm{~S}_{1}^{2}+\mathrm{S}_{2}{ }^{2}+\left(\mathrm{S}_{2}-\mathrm{S}_{1}\right)^{2}\right\}\right]$

$\mathrm{HI}(3)=1 /\left[3\left\{\mathrm{~S}_{1}^{2}+\mathrm{S}_{2}{ }^{2}+\mathrm{S}_{3}{ }^{2}+\left(\mathrm{S}_{2}-\mathrm{S}_{1}\right)^{2}+\left(\mathrm{S}_{3}-\mathrm{S}_{1}\right)^{2}+\left(\mathrm{S}_{3}-\mathrm{S}_{2}\right)^{2}\right\}\right]$

$\mathrm{HI}(4)=1 /\left[4\left\{\mathrm{~S}_{1}{ }^{2}+\mathrm{S}_{2}{ }^{2}+\mathrm{S}_{3}{ }^{2}+\mathrm{S}_{4}{ }^{2}+\left(\mathrm{S}_{2}-\mathrm{S}_{1}\right)^{2}+\left(\mathrm{S}_{3}-\mathrm{S}_{1}\right)^{2}+\left(\mathrm{S}_{4}-\mathrm{S}_{1}\right)^{2}+\left(\mathrm{S}_{3}-\mathrm{S}_{2}\right)^{2}+\left(\mathrm{S}_{4}-\mathrm{S}_{2}\right)^{2}+\left(\mathrm{S}_{4}-\mathrm{S}_{3}\right)^{2}\right\}\right]$

\section{The weakness of Formulas containing only one of The Harmony or the Gradation Only}

$>$ The weakness of the formulas containing only "The Harmony" is not to give the same index to a random variable (or set) that has the same nature but different sample populations.

$>$ The weakness of the formulas containing only "The Gradation" is to give the possibility that some random variables (or sets) of a different nature will get the same index

\section{The First Ten Implementations of "The Harmony in Gradation"}

It is said to be the first ten implementations as currently being developed other implementations.

Here are the ten implementations of "The Harmony in Gradation"

\subsection{Competition Law}

The Competition Law is not just about justice, but it is more a matter of money and economic stability because it is used as a way to maintain sustainability industry which is believed to happen when an industry has been run fair. In detail, the first step is to measure the "Competition Level" on an industry consisting of several firms, and if the result indicates that it is almost unfair or unfair, the Economic Judge may order steps to make the firms can compete fairly. One possibility, not yet certain, there are many other considerations, experts in the field that better understand, is to force firms that have a small market to merge. The weakness of the current formula, The Herfindahl-Hirschman Index, contains only the "The Harmony" element, causing a change in the $\mathrm{N}$ value causing the standard of interpretation of the nature of the random variable (or set) to change, as a result the judge may make the wrong decision, because 
they only see the HHI generated index simulation that does not change significantly, but does not realize that its meaning has changed drastically.

\subsection{Consistency Score on Pauli \& Kraepelin Test to measure Personality}

One method used to measure emotional stability is the Pauli \& Kraepelin test, which tells people to do the basic summation for 20 @ 3 minutes, then calculates 16 of the 20 measurement samples, and interprets the average deviation as a consistency score. This shows that this method uses a formula that contains only "The Gradation", and will cause the possibility that people with different emotional stability have been assessed equally. As a simple example of a test on two people, A who scores $\{5,7,5,7,5,5,7,5,5,7,7\}$ and $\mathrm{B}\{4,6,8,6,4,6,8,6,6$, $4,6,8,8,6,8,4\}$, will be judged to have the same emotional stability, since A and B are "seen" to have the same gradation. However, if the formula involves "The Harmony", then B which has "the Harmony" more, but has the same average as A, will "look" has a larger gradation, meaning "The Harmony in Gradation" will cause B score will be smaller than A.

\subsection{Inequality Index}

One of the formulas for calculating the Inequality Index is the Gini Index, whose formula contains only "The Gradation", which makes it possible for two random variables having different properties to be interpreted as the same. If Gini Index is only used to measure social inequalities such as inequality of people's incomes, its "weakness" will not show potential economic losses, which must be handled by the state. But if the Inequality Index is also used to measure the inequality of facilities and services to communities in the cities or provinces of a country, then the economic problems will be more "visible". In the calculation of such an inequality index, there is the possibility that big cities that have a nature "much higher" than the surrounding small towns, then considered to have the same index than small towns, because it is not "seen" by a formula that only has "The Gradation", then the State manager lets it unconsciously this will be a driver of migration of working age population to big cities, which will cause problems in big cities and reduce the productivity of small towns.

\subsection{Information Entropy}

The information entropy formula developed by Claude Shannon only has "The Harmony", it will cause problems when used in the field of cryptography, which "plays" the changes of the sample population, because the resulting index or entropy does not appear to change significantly when there is a change sample size, whereas based on measurement results, it is believed there has been a very significant change in properties. 
Especially for the matter of information entropy, the formula of "The Harmony in Gradation" must be modified, therefore the formula is called "Channel Cavity" because, in this area, the preferred unit is bits, and is presented in the following equation.

General formula:

$$
\begin{aligned}
& \text { Channel Cavity (bit) or Modified Information Entropy } \\
& \left.\qquad=\log _{2}\left[n *\left\{\sum_{i=1}^{n} p_{i}^{2}+\sum_{i=1}^{n} \sum_{j=1}^{n}\left(p_{i}-p_{j}\right)^{2}\right\}\right] ; i>j\right)
\end{aligned}
$$

Where: $\mathrm{n}=$ the size or number of symbols and $\mathrm{pi}=$ chance of the appearance of the $\mathrm{i}$-th symbol. Example formula:

$$
\text { Channel Cavity (bit) })_{n=2}=\log _{2}\left[2 *\left\{p_{1}^{2}+p_{2}^{2}+\left(p_{1}-p_{2}\right)^{2}\right\}\right]
$$

Channel Cavity $(\text { bit })_{n=3}$

$$
=\log _{2}\left[3 *\left\{p_{1}^{2}+p_{2}^{2}+p_{3}^{2}+\left(p_{1}-p_{2}\right)^{2}+\left(p_{1}-p_{3}\right)^{2}+\left(p_{2}-p_{3}\right)^{2}\right\}\right]
$$

\subsection{The Fairness over Inequality}

The method developed by Sigit Haryadi in August 2016 is to assess how fair an action or a policy has worked. The assumption used is that although there is an imbalance on a affected variable, $\mathrm{X}$, but the level of fairness of the action or policy against the affecting variable $\mathrm{X}$ expressed by variable $\mathrm{Y}$, is more fair, if the distribution of $\mathrm{Y}$ is more like the $\mathrm{X}$ distribution.

The simple example in the field of taxation policy of a country, for example, there is an imbalance in the distribution of income of the population (affected variable), then the tax policy of the country may be fair if the tax rate distribution imposed is like the distribution of income population. Please read in the reference below, there is proof that by referring to my theory, the more "fair" this policy, then the state income derived from tax will be the most optimum. Another example, in the field of a cellular telecommunication industry, for example, there is an imbalance in the distribution of the market share of its providers (affected variable), but if the distribution of the spectrum bandwidth provided by the state to the providers (affecting variable) is like the distribution of its market share, then the condition is said to be fair.

\subsection{Equality Correlation}

Equality correlation method is a statistical measure showing the extent to which the random variable being measured has similarities with the reference variable, where the determination of the correlation index is done by calculating the Haryadi Index of the relationship between the random variable as measured by the reference variable. In this case, an index equal to one represents a perfect similarity between the elements of the variable as measured by the pairs of elements of the reference variable, let $R$ be the reference variable $=\{1,2,3,4,5,6,7,8,9,10$, 
$11\}$ and $\mathrm{Y}$ is random variable measured $=\{2,4,6,8,10,12,14,16,18,20,22\}$, then $\mathrm{Y}$ has an equity correlation index equal to one through the relationship function $\mathrm{Y}=2 \mathrm{R}$, since all elements of $\mathrm{Y}$ are equal to twice of the pairing elements of $\mathrm{R}$.

\subsection{Linear Regression without Intercept}

This method is made in accordance with a formula made by Sigit Haryadi in August 2016, take a look in the references.

The Advantages compared to Pearson's correlation are:

a) It would be better to use when we are sure that the regression equation has no intercept, which means the dependent variable is zero when the independent variable = zero

b) The hypothesis of the Regression equation, correlation index between variables, and confidence level of the regression equation will be obtained directly without the test and $\mathrm{F}$ test

c) The result remains accurate for any sample population (sample> $=2$ ).

\subsection{Calculation the Equity Level of an Internet Service}

The method of calculating the level of equity of internet services of several cities or provinces in a country is a statistical measure showing how far the internet service speed distribution being measured is to have similarities with the reference distribution of all elements equal to one, where the determination of the level of equity is done by calculating the Index Haryadi from the relationship between internet service speed distribution as measured by reference distribution. In this case, an equalization index equal to one represents a perfect similarity between the elements of the distribution as measured by the pairs of elements of the reference distribution. Let $\mathrm{R}$ be the reference distribution $=\{0.7 \mathrm{Mbps} ; 0.8 \mathrm{Mbps} ; 0.9 \mathrm{Mbps} ; 1 \mathrm{Mbps} ; 1.1$ Mbps; 1.2 Mbps; 1.3 Mbps; 1.4 Mbps $\}$ and $\mathrm{Y}$ is the measured internet rate $==1.05 \mathrm{Mbps} ; 1.2$ Mbps; 1.35 Mbps; 2 Mbps; 1.65 Mbps; 1.8 Mbps; 1.95 Mbps; 2.1 Mbps \}, then Y has an Internet service equalization index equal to one, through the $\mathrm{Y}=1.5 \mathrm{R}$ relationship function because all elements of $\mathrm{Y}$ are equal to 1.5 times of the pairing elements of $\mathrm{R}$.

\subsection{Competition Levels among Students in Class vs. Teacher or Lecturer Fairness in Teaching}

Measuring the level of competition among students or students taking place in the classroom and its relation to the level of fairness of teachers or lecturers teaching on this "internet calculator" is made by using the formula from Sigit Haryadi called "Haryadi Index" and found in April 2016.

This method is very important because during this time the majority of teachers and lecturers who teach in the class never introspect whether he was fair to his students in the class he taught. 
The results obtained by the calculator are (a) competition index among students in the class, (b) Competition level among students in the classroom accompanied by an analysis of competition situation that occurs in the classroom with the level of fairness of teachers or lecturers in teaching.

The result of the calculation using the Haryadi Index states that: (1) index $>=0.75$ indicates that the competition among students in the class is Balanced which means that the class has run normally, where the students 'or students' ability to absorb the lesson is relatively even, and the teacher or lecturers have taught fairly; (2) 0.75 index $=0.5$ indicates the existence of competition among students in the class is less balanced, which means the class has run less normal, where the ability of students to absorb the lesson is relatively uneven and/or teachers or lecturers have taught with a bit unfair; (3) index 0.5 indicates the existence of competition among students in the class is very unbalanced, which means the class has been running abnormally, where the ability of students or students to absorb the lesson is very uneven and/or teachers or lecturers have taught unfair.

\subsection{The Government Policy to make a Fair Policy of TAX RATE}

This formula was created by Sigit Haryadi and Westi Riani in August 2017, with the aim of being used by the finance ministry in a country in determining the percentage of income tax. When using this calculator, each country must determine how many groups of tax rates, if desired, there are three levels, just for example, then the citizens of the taxpayers are divided into three groups: the rich, the middle, and below the average. Each country is free to decide whether to make 2,3 , or 4 , or more income groups that each income group will be subject to a fair tax rate, where the fair definition here is that the tax rate will be greater with higher income. The parameters that determine the tax rates are: the number of income groups, Fairness Level, Tax target, Target of GDP, total population and the amount of employment that becomes the taxpayer.

In this calculator, a new parameter: "Fairness Level", which is the level of honesty or compliance of citizens in terms of paying income tax, whose value is among 0.1 to 1.0. If citizens become more obedient then tax rates will seem more fair, but if more disobedient citizens then tax rates will be more unfair, meaning the percentage of taxes will be higher comparing to tax rates in the country where all citizens are honest. So as a result of dishonest or disobedient citizens, an impact on a dutiful citizen will pay a greater percentage of tax. 


\section{Note}

In order to better understand the concept of "Harmony in Gradation" or "Haryadi Index" which became the spirit of this "Formula of Everything" is welcome to read the papers and books contained in the bibliography as follows.

\section{References}

[1] Sigit Haryadi. (2017). Haryadi Index and Its Applications in Science of Law, Sociology, Economics, Statistics, and Telecommunications. Penerbit Elex Media Komputindo. Jakarta. ISBN: 978-602-02-9895-5.

[2] Sigit Haryadi. (2017). Indeks Haryadi dan Penerapan di Ilmu Hukum, Sosiologi, Ekonomi, Statistik, dan Telekomunikasi. Penerbit Elex Media Komputindo, Jakarta. ISBN: 978-602-02-9896-2

[3] Sigit Haryadi. (2016). Haryadi Index for Competition, Equality and Correlation Evaluation. Penerbit Lantip Safari Media, Bandung, Indonesia. ISBN: 978-602-732313-2

[4] Sigit Haryadi. (2016). Haryadi Index untuk Evaluasi Kompetisi, Kesetaraan dan Korelasi. Penerbit Lantip Safari Media, Bandung, Indonesia. ISBN: 978-602-73231-31

[5] Sigit Haryadi. (March 17, 2018). The Six 100-year-old Formula Should be Replaced. Researchgate. DOI 10.13140/RG.2.2.21919.66723

[6] Haryadi, S. (2018, March 17). Sepuluh Implementasi Yang Pertama untuk Membuktikan bahwa "The Harmony in Gradation" adalah "The Formula Everything". Retrieved from osf.io/preprints/inarxiv/ja9ve

[7] Haryadi, S., \& California, S. H. (2018, March 14). New Method to Calculate the Level of Consistency of the Pauli \& Kraepelin Tests. Retrieved from osf.io/preprints/inarxiv/ty326

[8] Haryadi, S., \& California, S. H. (2018, March 14). Metoda Baru Untuk Menghitung Tingkat Konsistensi pada Tes Pauli \& Kraepelin. Retrieved from osf.io/preprints/inarxiv/qht8j

[9] Haryadi, S. (2018, March 6). Calculation the Equity Level of an Internet Service. Retrieved from osf.io/uzcmq

[10] Haryadi, S. (2018, March 6). Perhitungan Tingkat Pemerataan Layanan Internet. Retrieved from osf.io/preprints/inarxiv/rgct3

[11] Dyah Rakhma Ariyanti; Sigit Haryadi. (October 2017). Analysis of Harmony In Gradation Index on 5G Cellular Network Quantitative Analysis. The 11th International Conference on Telecommunication Systems, Services, and Applications, At Lombok, Indonesia.

[12] Haryadi, S. (2017, November). Probabilitas Statistik Untuk Insinyur. Researchgate. DOI: $10.13140 / R G \cdot 2.2 .14304 .58885$

[13] Haryadi, S. (2018, February 1). Indeks Haryadi dan Prospeknya Untuk Menjadi Suatu "Formula of Everything (versi 31 Desember 2017). Retrieved from osf.io/zex45

[14] Haryadi, S. (2018, February 1). KALKULATOR untuk membuat Regresi Linier Tanpa Intersep. Retrieved from osf.io/emvs7

[15] Haryadi, S. (2018, February 1). Kalkulator Untuk Mengukur Tingkat Kompetisi di suatu Industri, dengan menggunakan rumus Indeks Haryadi. Retrieved from osf.io/fy7zu 
[16] Haryadi, S. (2018, February 17). Calculation the Competition Levels between Students in Class and the Relation to the Teacher or Lecture Fairness in Teaching. Researchgate. DOI: $10.13140 /$ RG.2.2.30359.06569

[17] Haryadi, S. (2018, February 17). Perhitungan Tingkat Kompetisi antar Murid atau Mahasiswa di Kelas dan Kaitannya Dengan Keadilan Guru atau Dosen Dalam Mengajar. Retrieved from osf.io/a894w

[18] Haryadi, S. (2018, February 22). Equality Correlation Calculation. Researchgate. DOI: 10.13140/RG.2.2.22068.76168

[19] Haryadi, S. (2018, February 22). Kalkulator Untuk Menghitung Korelasi Kesetaraan. Retrieved from osf.io/preprints/inarxiv/7r9jy

[20] Haryadi, S. (2018, February 24). Calculation of "Channel Cavity" on Data Communications. Equality Correlation Calculation. Research gate. DOI: 10.13140/RG.2.2.30536.01288

[21] Haryadi, S. (2018, February 24). Perhitungan "Rongga Kanal" pada Komunikasi Data. Retrieved from osf.io/preprints/inarxiv/y3wcg

[22] Haryadi, S. (2018, February 28). Ikhtisar Organisasi Regulasi Telekomunikasi. Retrieved from osf.io/preprints/inarxiv/g9m3k

[23] Haryadi, S. (2018, February 7). Statistik Terapan: Pengujian Regulasi \& Kebijakan Telekomunikasi. Retrieved from osf.io/3pkfw

[24] Haryadi, S. (2018, January 25). Chapter 1. The Concept of Telecommunication Network Performance and Quality of Service. Retrieved from osf.io/mukqb

[25] Haryadi, S. (2018, January 26). Chapter 2 of Network Performance and Quality of Service: Determination of Key Performance Indicator (KPI). Retrieved from osf.io/preprints/inarxiv/6gtnd

[26] Haryadi, S. (2018, January 26). Chapter 3 of Network Performance and Quality of Service: Technical Measurement of a Mobile Network Performance and Quality of Service. Retrieved from osf.io/q4wsz

[27] Haryadi, S. (2018, January 30). Basic Calculation of the Network's Availability and Reliability (Chapter 4 of Network Performance and Quality of Service). Retrieved from osf.io/preprints/inarxiv/z5mwq

[28] Haryadi, S. (2018, March 1). Kebijakan Lisensi Telekomunikasi. Retrieved from osf.io/7wbjf

[29] Haryadi, S. (2018, March 5). Performance Measurement of Internet Service. Retrieved from osf.io/9nsw3

[30] Haryadi, S., \& Riani, W. (2018, March 5). METODE PENETAPAN TARIF PAJAK PENGHASILAN YANG BERKEADILAN. Retrieved from osf.io/preprints/inarxiv/ayg58

[31] Nie Levin Kusuma Adiatma ; Sigit Haryadi. (2017, October). Comparison of the Haryadi Index with Existing Method in Competition, Equality, Fairness, and Correlation Level Calculation Case Study: Telecommunication Industry. The 11th International Conference on Telecommunication Systems, Services, and Applications, At Lombok, Indonesia.

[32] Sigit Haryadi. (2017). Calculation of the Mobile Communication Competition using Haryadi Index. DOI: 10.13140/RG.2.2.15634.25280

[33] Sigit Haryadi. (2017). Harmony in Gradation and and its prospects as the Formula of Everything (First edition of posts: December 31, 2017). Researchgate. DOI: 10.13140/RG.2.2.19309.08169

[34] Sigit Haryadi. (2017). the Equality Correlation Method. Researchgate. DOI: 10.13140/RG.2.2.10443.80169. 
[35] Sigit Haryadi. (2017). The Non-Intercept Linear Regression Method. Researchgate. DOI: 10.13140/RG.2.2.18721.71522

[36] Sigit Haryadi. (2017). The Fairness over Inequality Index: Unfairness is Disaster - a notebook of Sigit Haryadi. Researchgate. DOI: 10.13140/RG.2.2.34379.49449.

[37] Sigit Haryadi. (2017, December). Calculator for Measurement the Competition Index \& Level. Researchgate. DOI: 10.13140/RG.2.2.23626.26568

[38] Sigit Haryadi. (2017, December). Calculator for non intercept linear regression. Researchgate. DOI: 10.13140/RG.2.2.15761.94562.

[39] Sigit Haryadi. (2017, January). Calculation of the Income Equality Levels between Regions using the Haryadi Index. Researchgate. DOI: 10.13140/RG.2.2.36605.77282

[40] Sigit Haryadi. (2018, February). Applied Statistics for Assessment of the Regulation and Policy: case study in Telecommunication Industry. DOI: 10.13140/RG.2.2.15774.02884

[41] Sigit Haryadi; Dyah Rakhma Ariyanti. (October 2017). The Fairness of Resource Allocation and Its Impact on 5G Ultra-Dense Cellular Network Performance. The 11th International Conference on Telecommunication Systems, Services, and Applications, At Lombok, Indonesia.

[42] Westi Riani; Sigit Haryadi. (2017). CALCULATOR for the Government to make the Fair Policy of Tax Rates. Researchgate. DOI: 10.13140/RG.2.2.18550.50246. Available online at http://sigitharyadi.net/multidicipline/income-tax-rates-calculator$\underline{\mathrm{id} /}$

[43] Westi Riani; Sigit Haryadi. (2017). The Method Of Tax Rate Determination Based On Fairness. Prosiding Seminar Nasional SNaPP2017, Bandung, Indonesia.

[44] Haryadi, S., \& Riani, W. (2018, March 12). Telecommunication Competition and Interconnection. Retrieved from osf.io/preprints/inarxiv/7tfqd

[45] Westi Riani; Sigit Haryadi. (2017). Prosiding SNaPP2017 "THE METHOD OF TAX RATE DETERMINATION BASED ON FAIRNESS". Conference: Seminar Nasional Penelitian dan PKM (SNaPP) 2017At: Bandung, Indonesia.

[46] Sigit Haryadi. (2017). Tantangan Untuk Menerapkan Haryadi Index pada Ilmu Fisika. Jurnal Pendidikan Fisika Sekolah Menengah. Jurnal Pendidikan Fisika Sekolah Menengah. Vol 9 no 1 2017. ISSN: 1979-4959. Available at : https://www.researchgate.net/publication/316683866 